\title{
In vitro culture of the Ural endemic Gypsophila uralensis Less. (Caryophyllaceae)
}

\author{
Zh. E. Mikhovich*, L. V. Teteryuk \\ Institute of Biology of Komi Science Centre of the Ural Branch of the Russian Academy of Sciences, Kommunisticheskaya St., 28, \\ Syktyvkar,167982,Russian Federation.E-mails:mihovich@ib.komisc.ru*; teteryuk@ib.komisc.ru \\ * Corresponding author
}

Keywords: composition of nutrient media, endemic species of the Urals Gypsophila uralensis Less., microclonal propagation.

Summary. The culture of loose light green callus tissue from seedlings Gypsophila uralensis Less. was obtained using Murashige-Skoog (MS) and Woody Plant Medium (WPM) with the addition of BA $1.0 \mathrm{mg} / 1+$ IAA $0.1 \mathrm{mg} / 1$ (where BA = 6-benzylaminopurine and IAA = Indolyl-3-acetic acid). Callus had a high morphogenic activity for four passages. The percentage of viable callus varied from $82 \%$ to $94 \%$. The average number of fragments per callus was $6.2 \pm 0.4$ on MS and $4.5 \pm 0.4$ on WPM. With prolonged cultivation (more than eight weeks), the callus darkened and died. The transition from callus proliferation to organogenesis was noted when the MS medium changed to Silene cretacea Saratov (SCS) medium. Further induction of morphogenesis took place on SCS medium with a complex set of growth regulators (BAP $0.2 \mathrm{mg} / 1+\mathrm{IAA} 0.5 \mathrm{mg} / 1+\mathrm{CIN} 1.0 \mathrm{mg} / 1+\mathrm{HA} 1.0 \mathrm{mg} / 1$ ). Up to $90 \%$ of the callus switched to the formation of adventitious shoots after four to six weeks of cultivation. 2 to 13 shoots developed with a height of up to $2 \mathrm{~cm}$ with 2-4 pairs of well-developed green leaves depending on the size of the callus. Rhizogenesis was observed only on the WPM nutrient medium with the addition of IAA auxins from $0.1 \mathrm{mg} / 1$ to $1.0 \mathrm{mg} / 1$ and IAA $0.2 \mathrm{mg} / 1+$ IBA $0.5 \mathrm{mg} / 1$ (where IBA = indolylbutyric acid). The beginning of the formation of roots was observed after three to four weeks. The proportion of rhizogenesis was 51-53\%, i. e. both an increase in the concentration of IAA and the addition of IMA to the medium didn't lead to an increase in the number of microturns with roots. The possibility of obtaining regenerated plants in the callus culture of Gypsophila uralensis was shown.

\section{Введение в культуру in vitro эндемика Урала Gypsophila uralensis Less. (Caryophyllaceae)}

\author{
Ж. Э. Михович, Л. В. Тетерюк
}

\begin{abstract}
Институт биологии Коми научного иеетра Уральского отделения Российской академии наук, ул. Коммунистическая, д. 28, г. Сыктывкар, 167982, Россия
\end{abstract}

Ключевые слова: микроклональное размножение, состав питательных сред, эндемичный вид Урала Gypsophila uralensis Less.

Аннотация. Впервые введен в культуру in vitro эндемичный для Урала вид Gypsophila uralensis Less. (качим уральский). Получена культура рыхлой светло-зеленой каллусной ткани из проростков на средах Мурасиге-Скуга и WPM с добавлением БАП 1,0 мг/л + ИУК 0,1 мг/л, которая в течение четырех пассажей обладала высокой морфогенной активностью. Доля жизнеспособных каллусов варьировала от 82 до $94 \%$. Среднее число фрагментов на один каллус составило 6,2 $\pm 0,4$ на среде MS и 4,5 $\pm 0,4$ на среде WPM. При длительном 
культивировании (более восьми недель) каллус темнел и погибал. Переход от пролиферации каллуса к органогенезу отмечен при смене среды MS на SCS. Дальнейшая индукция морфогенеза проходила на среде SCS со сложным набором регуляторов роста (БАП 0,2 мг/л + ИУК 0,5 мг/л + КИН 1,0 мг/л + ГК 1,0 мг/л), до 90 \% каллусов через четыре - шесть недель культивирования переходили к формированию адвентивных побегов. В зависимости от размера каллуса развивалось от 2 до 13 побегов, высотой до 2 см с 2-4 парами хорошо развитых зеленых листьев. Ризогенез отмечен только на питательной среде WPM с добавлением ауксинов ИУК от 0,1 мг/л до 1,0 мг/л и ИУК 0,2 мг/л + ИМК 0,5 мг/л. Начало формирования корней наблюдалось через три четыре недели. На средах с концентрацией ИУК от 0,1 до 1,0 мг/л и ИУК 0,2 + ИМК 0,5 мг/л доля микропобегов с корнями составила 51-53 \%, т. е. как повышение концентрации ИУК, так и добавление ИМК в среду не приводило к увеличению числа микропобегов с корнями. Показана возможность получения растений регенерантов в каллусной культуре Gypsophila uralensis.

\section{Introduction}

Gypsophila uralensis Less. is a high-mountain endemic of the Urals (Gorchakovskij, 1963). The species is especially widespread in the southern part of the Ural range; however, it becomes rare to the north and is subject to protection (Gorchakovsky, 2008; Puchnina, 2008; Teteryuk, 2009; etc.). The relic locations of $G$. uralensis in the European Northeast of Russia and in the northern part of the Urals are associated with the Late Pleistocene cover glaciations (Andreicheva, 2002). The species is found as part of a relict petrophytic floristic complex in the basins of the Shchugor, Kozhim, Lemva and Khaimah rivers on the western macro slope of the Northern and Subpolar Urals. Two small fragments of the G. uralensis range are preserved in the taiga zone - in the Arkhangelsk Region (in the valleys of the Pinega, Sotka, Soyana and Northern Dvina rivers) and in the Komi Republic (Middle Timan: in the valleys of the Myla, Pechorskaya Pizhma and Svetlaya rivers). Gypsophila uralensis Less. subsp. pinegensis (Perf.) Kamelin (= G. pinegensis Perf.) (Perfilyev, 1941) is described from samples of the Arkhangelsk region. It is included in the Red Book of the Russian Federation (Kamelin, 2008). Timan populations of a species are also genetically differentiated (Teteryuk et al., 2018). The vulnerability of relic populations of G. uralensis is associated with their small size, ecological specificity and low competitiveness of the species, as well as the destruction of its natural habitats. Territorial protection of the species is carried out in the national park "Yugyd Va", Pechora-Ilychsky Reserve, and reserves "Pizhemsky", "Mylsky" and "Svetly". An implementation of the species into culture and the development of approaches to the reconstruction of its small populations are the next step for the successful conservation of G. uralensis and in the future - other species of relict petrophytic floristic complex.
Biotechnological approaches (Sathe et al., 2013; Kritskaya et al., 2016; Ivashuk et al., 2017; Ambros et al., 2018; Erst et al., 2018; Ivashchuk et al., 2018; Del Vecchio et al., 2019; Erst et al., 2019) including micropropagation are used with great success in Russia and abroad for conservation, reproduction and studying rare plant species. Works on micropropagation of $G$. uralensis are absent in the literature. The most effective method in micropropagation is the method of culture of apical meristem. It is the main mass reproduction method, surpassing traditional vegetative reproduction. The disadvantages of this method include the need for targeted cultivation of mother plants, which is almost impossible with rare plant species, and a limited number of apexes on it. This problem can be overcome by using another method of micropropagation - induction of morphogenesis in callus tissue. The main problem of this approach is possible mutations in tissue culture. Therefore, there are several requirements when using this method: preservation of genetic stability and high regenerative ability of transplantation callus with repeated passages. Pícea ábies, Pinus pinaster, and P. canariensis (Kataeva, Butenko, 1983; Kalashnikova, Rodin, 2004) are successfully propagated by callus genesis.

The aim of our study is to identify the prospects of using the cell culture method to obtain and accelerate reproduction of the endemic Ural G. uralensis by callus genesis.

\section{Materials}

The work was done in the Botanical Garden Department of the Institute of Biology of the Komi SC UrB of RAS in 2017-2018.

Objects. The object of the study was G. uralensis seeds collected in places of natural growth (02.08.2012, Subpolar Ural, Kozhim River, Eagle Nest tract). To obtain primary callus, seedlings with 
removed roots were used as explants. The number of explants (n) -10 , the number of repetitions -3 .

Reagents. Soap solution of household soap domestic bleach Domestos (LLC Unilever Rus), ethyl alcohol $95 \%$ (ZAO ROK), Hexadecylpyridinium chloride monohydrate (Sigma-Aldrich) and Ethylmercury chloride (Sigma-Aldrich) were used for preparation of diacide. It was used to disinfect the surface of the seeds. Vitamins (Sigma-Aldrich) and phytohormones (Sigma-Aldrich), sucrose (NevaReaktiv), agar-agar (Himreaktivsnab) were used to prepare a nutrient medium.

Equipment. Disinfection of dishes and tools was carried out in a UFE 400 oven, a sterilization of nutrient media was achieved in a steam sterilizer model $2540 \mathrm{ML}$, and acidity of the nutrient media was measured on a Ph meter (Ph-150 MI). All work was performed in a laminar box (Laminar-C), and aseptic conditions were required for each step. The ultraviolet-bactericidal air recirculator (Dezar) was used to destroy vegetative and spore forms of pathogenic and non-pathogenic microorganisms in the laboratory.

Statistical data processing was accomplished using Microsoft Excel 2007. Analysis of the results was performed using analysis of variance. The Duncan test was performed with an average value of $\mathrm{P}=0.05$.

\section{Method execution}

Preparation and sterilization of nutrient media and instruments was carried out according to the recommendations (Butenko, 1964; Kataeva, Butenko, 1983; Kalinin et al., 1992; Kalashnikova, Rodin, 2004). Surface sterilization of seeds was carried out in two stages. At the first stage, seeds were soaked in septic conditions in a soap solution for $20 \mathrm{~min}$ utes, then washed in running water and kept in 10 $\%$ Domestos for 5 minutes. At the second stage, the seeds were treated under the aseptic conditions of the laminar box with $70 \%$ ethyl alcohol for $20 \mathrm{sec}-$ onds and kept in $0.1 \%$ diacide for 5 minutes. Seeds $(10$ pcs.) were placed in glass jars (in triplicate). This sterilization scheme resulted in $100 \%$ sterility and explant survival. Nutrient media was used for cultivation as described by Murashige and Skoog (MS) (Murashige et al., 1962), medium WPM (Lloyd et al., 1980), and also medium SCS (Kritskaya et al., 2015). This medium with a set of growth regulators (BA $0.2 \mathrm{mg} / 1+\mathrm{GA}_{3} 1.0 \mathrm{mg} / 1+\mathrm{KIN} 1.0 \mathrm{mg} / 1+$ IAA $0.5 \mathrm{mg} / 1$ ) is used as a nutrient medium for the rare calcephilic plants reproduction obtained by di- rect organogenesis in an in vitro culture (Kritskaya et al., 2015, 2016). Vitamins and amino acids were added as prescribed by MS. Sucrose was used at a concentration of $2 \%$ in WPM and SCS medium as a carbon nutrition source, in MS medium - $3 \%$; in other medium - agar $0.8 \%$. The $\mathrm{pH}$ was adjusted to 5.8 (MS) and 5.9-6.0 (WPM and SCS) in nutrient media using $0.1 \mathrm{~N} \mathrm{NaOH}$ prior to autoclaving. IAA and IBA were used as auxins, BA and CIN were used as cytokinins, gibberellic acid $\left(\mathrm{GA}_{3}\right)$ as gibberellin. Nutrient media of $20 \mathrm{ml}$ were poured into $100 \mathrm{ml}$ pre-sterilized glass jars, covered with food foil on top and sterilized in a model 2540 ML steam sterilizer for 10 minutes at a pressure of $1 \mathrm{~atm}$. and a temperature of $120{ }^{\circ} \mathrm{C}$. Banks with a sterile culture medium were kept at room temperature for 3 days before use to detect latent infection. Tweezers, disposable eye scalpels and Petri dishes were used for sowing seeds, picks and division callus. Tweezers and glassware were pre-sterilized in a heating oven at $110{ }^{\circ} \mathrm{C}$ for 4 hours. Work in sterile conditions was carried out in a microbiological box; before the work, to kill any infection in the laboratory, procedures included using an irradiator-recirculator of air ultraviolet-bactericidal for two hours. The light source was cold white fluorescent lamps with an intensity of up to 3000 lux for 16 hours a day. Relative air humidity was maintained at $60-70 \%$, air temperature was $24 \pm 2{ }^{\circ} \mathrm{C}$.

The seeds were injected on nutrient media according to the prescriptions of MS and WPM without adding hormones. Seed germination was $80 \%$ on the eighth day of cultivation in both variants of the experiment (Fig. 1). The seedlings had a main root up to $2.5 \mathrm{~cm}$ long and cotyledons). Sprouts with removed roots were transferred to fresh nutrient media MS and WPM supplemented with BA $1.0 \mathrm{mg} /$ 1, IAA $0.1 \mathrm{mg} / 1$, BA $0.2 \mathrm{mg} / 1$ after 20 days and cultured for four to eight weeks. A loose light-green callus which was actively growing and did not lose its morfogenic activity for a long time was formed at the base of the shoot in all explants. Callus culture was characterized by morphological characteristics (consistency and color). Tissue growth and viability were evaluated visually. Subsequently, passivated callus, reached a diameter of 2-4 cm, were divided into parts with a scalpel. Then the callus fragments were transferred to the same, but fresh nutrient media under sterile conditions of the laminar box. Subculture was performed 4 times. The number of fragments per callus was taken as the number of parts received from one callus per passage. Passage of fragment callus was performed four times; on aver- 
age, the duration of one passage was $47 \pm 6$ days. The volume of callus tissue increased more than 2.5 times during this period. The frequency of callus formation was high and varied from 82 to $94 \%$. The average number of fragments per callus was $6.2 \pm$ 0.4 on MS and $4.5 \pm 0.4$ on WPM (Table 1).

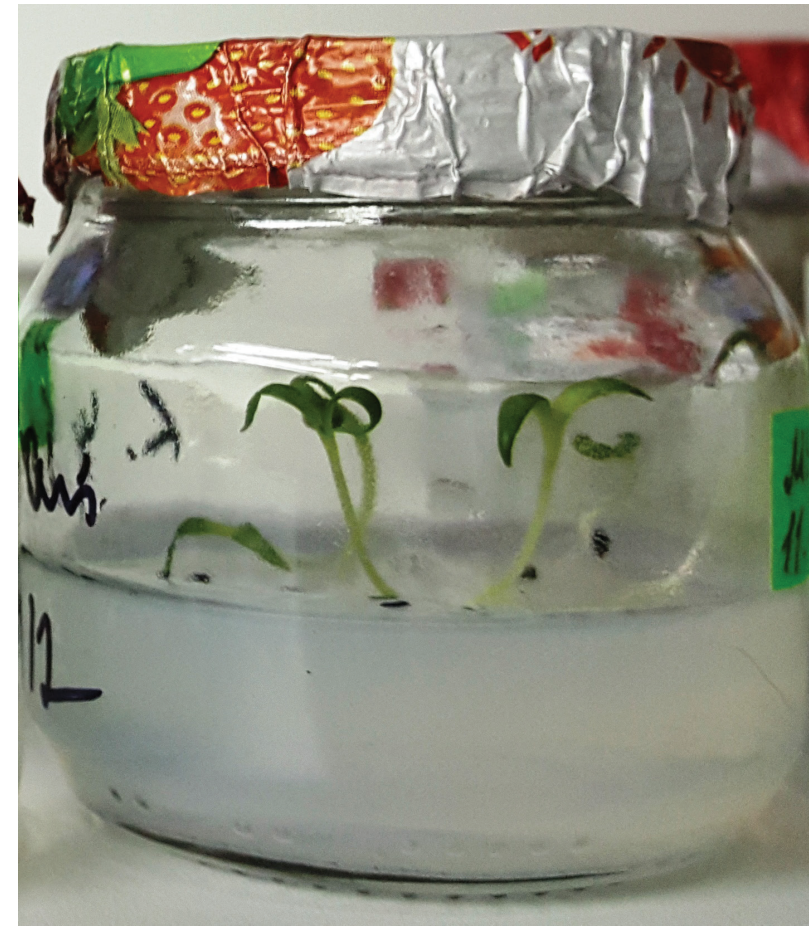

Fig. 1. Gypsophila uralensis implementation in in vitro culture on the harmonious MS medium (14th cultivation's day).

Loose light-green calluses broke up into separate fragments, a denser callus was divided with a scalpel (Fig. 2).

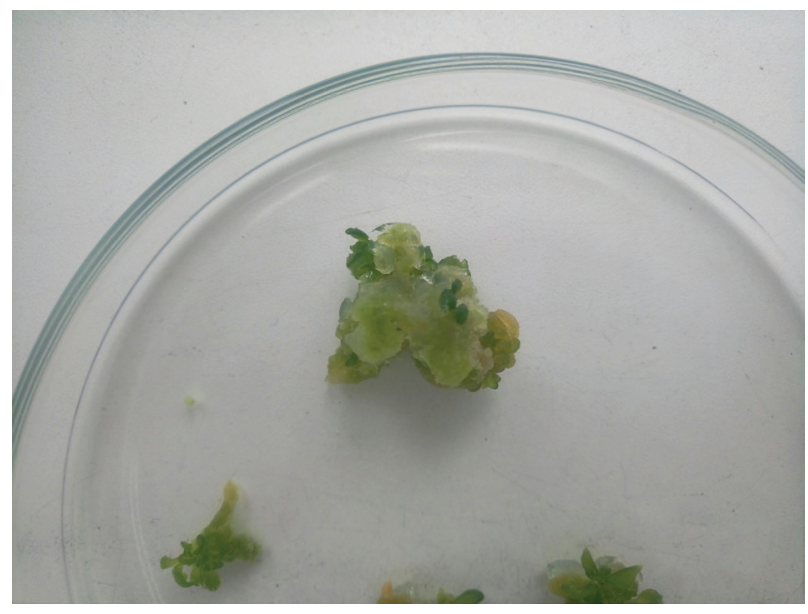

Fig. 2. Callus tissue Gypsophila uralensis formation on the MS medium with the addition of BA $1 \mathrm{mg} / 1$ and IAA $0.1 \mathrm{mg} / 1$. Callus contains fragments used for further subculture.
Callus darkened and died during long-term cultivation (more than 8 weeks). The transition from callus proliferation to organogenesis was observed only when the MS medium was changed to SCS. The grafts were transferred to SCS medium with a complex set of growth regulators (BA $0.2 \mathrm{mg} / 1+$ IAA $0.5 \mathrm{mg} / 1+\mathrm{CIN} 1.0 \mathrm{mg} / 1+\mathrm{GA}_{3} 1.0 \mathrm{mg} /$ 1) for further induction of morphogenesis, up to 90 $\%$ of the callus mass was morphogenic. Adventive micro shoots formed on a transfer callus from 2 to 13 pieces up to $2 \mathrm{~cm}$ tall, with $2-4$ pairs of welldeveloped green leaves, depending on its size, after four to six weeks of cultivation on passivated callus (Fig. 3). There was a shoots elongation and a roots formation on the WPM medium with the addition of auxins (Fig. 4, 5). WPM nutrient medium was used with addition of IAA auxins from $0.1 \mathrm{mg} / 1$ to 1.0 $\mathrm{mg} / 1$ and IAA $0.2 \mathrm{mg} / 1+0.5 \mathrm{mg} / 1 \mathrm{IBA}$ for rhizogenesis. The beginning of the formation of roots was observed after three to four weeks. The roots had a white color, were numerous, thin and brittle. When $0.1 \mathrm{mg} / 1$ IAA was introduced into a medium, the proportion of rhizogenesis was $53 \%$ (Table 2). Both an increase of IAA concentration up to $1 \mathrm{mg}$ $/ 1$ and adding IBA im medium did not lead to the increase of number of shoots with roots. Regenerants were ready to land in five weeks from the start of cultivation.

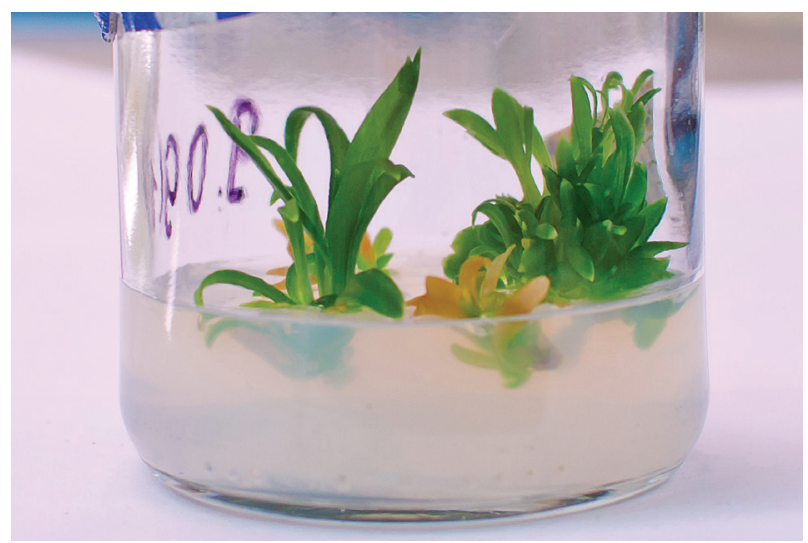

Fig. 3. Micropropagation Gypsophila uralensis on the SCS medium.

G. uralensis callus tissue cells are competent because they have a different morphogenetic response to the action of auxins and cytokinins. When auxins were introduced into the nutrient medium, roots were formed, and when cytokinins, gibberellins and auxins were added together, shoots were formed. The simultaneous differentiation of unrelated micro shoots and roots from fragment callus was noted. 
No visible morphological differences between intact plants and regenerants were noted. Genetic studies

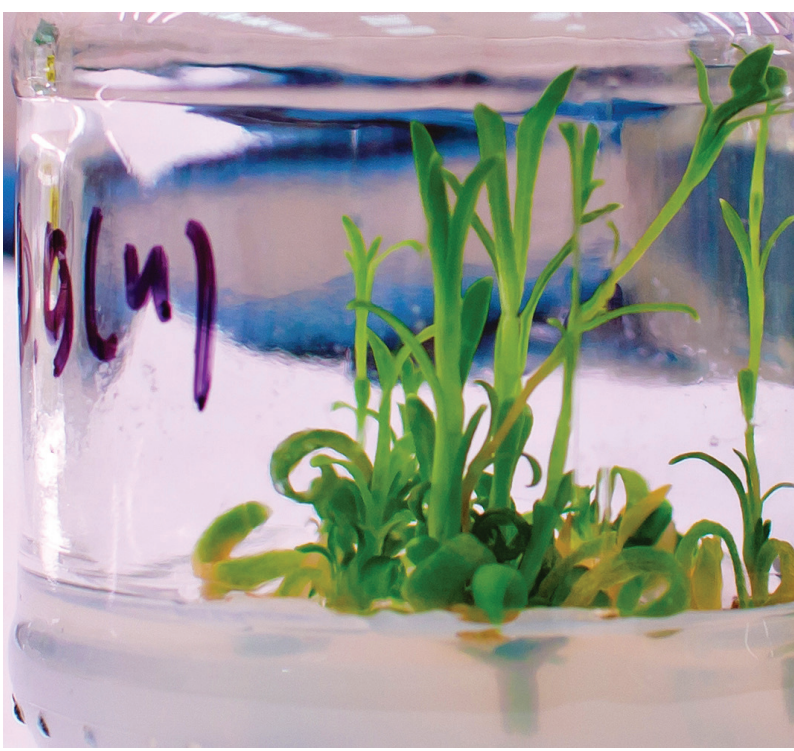

Fig. 4. Shoots elongation of Gypsophila uralensis on WPM medium with an IBA $0.5 \mathrm{mg} / 1+$ IAA $0.2 \mathrm{mg} / 1$. have not been conducted due to insufficient material.

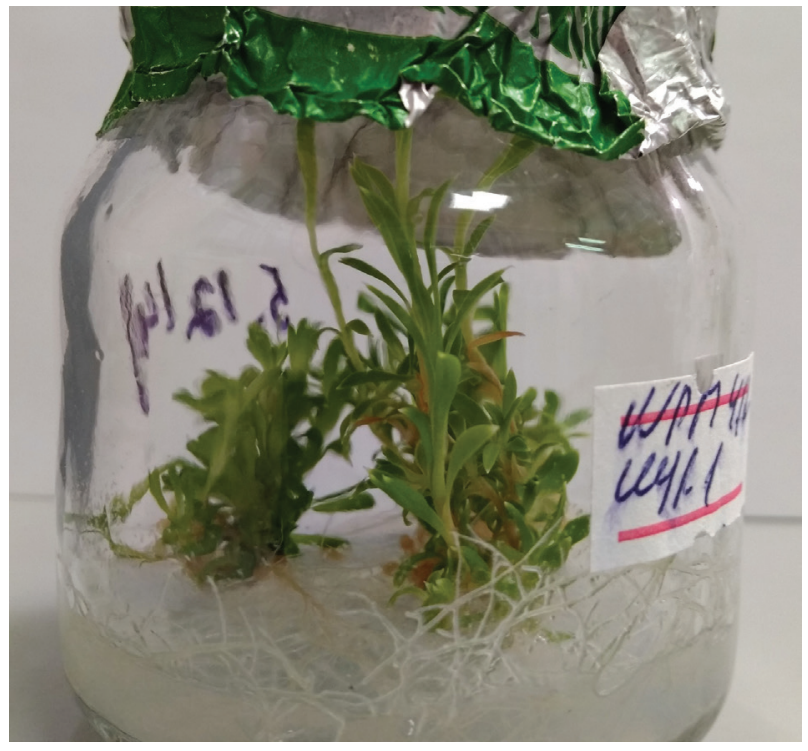

Fig. 5. Gypsophila uralensis regenerates, ready for planting in the ground (culture age is 45 days; medium WMP + IAA $1 \mathrm{mg} / 1)$.

Table 1

The percentage of viable callus and the number of fragments per callus of Gypsophila uralensis callus culture, depending on the mineral composition of the nutrient medium and the content of growth regulators

\begin{tabular}{|c|c|c|c|c|c|}
\hline \multirow{2}{*}{ № passage } & \multirow{2}{*}{$\begin{array}{c}\text { Growth regulators, } \\
\mathrm{mg} / 1\end{array}$} & \multicolumn{2}{|c|}{ MS } & \multicolumn{2}{c|}{ WPM explants that } \\
& formed callus & $\begin{array}{l}\text { number of } \\
\text { fragments per } \\
\text { callus, pcs. }\end{array}$ & $\begin{array}{l}\text { \% explants that } \\
\text { formed callus }\end{array}$ & $\begin{array}{c}\text { number of } \\
\text { fragments per } \\
\text { callus, pcs. }\end{array}$ \\
\hline 1 & BA1.0 + IAA 0.1 & $93.6 \pm 5.0$ & $7.1 \pm 1.7$ & $83.8 \pm 4.4$ & $5.1 \pm 0.6$ \\
\hline 2 & BA 0.2 & $83.8 \pm 8.0$ & $6.1 \pm 2.4$ & $85.6 \pm 4.4$ & $4.7 \pm 0.6$ \\
\cline { 2 - 6 } & BA 1.0 + IAA 0.1 & $90.5 \pm 3.0$ & $8.1 \pm 1.1$ & $87.6 \pm 5.3$ & $6.4 \pm 1.6$ \\
\hline \multirow{2}{*}{3} & BA 0.2 & $83.4 \pm 4.0$ & $5.4 \pm 1.1$ & $85.4 \pm 4.8$ & $3.6 \pm 0.7$ \\
\cline { 2 - 6 } & BA 1.0 + IAA 0.1 & $87.2 \pm 5.8$ & $5.8 \pm 1.0$ & $81.6 \pm 4.2$ & $3.8 \pm 0.6$ \\
\hline \multirow{2}{*}{4} & BA 0.2 & $87.4 \pm 4.0$ & $5.2 \pm 0.7$ & $85.6 \pm 4.8$ & $3.9 \pm 0.7$ \\
\cline { 2 - 6 } & BA 1.0 + IAA 0.1 & $86.4 \pm 5.0$ & $5.6 \pm 0.6$ & $86.0 \pm 4.4$ & $4.1 \pm 0.6$ \\
\hline
\end{tabular}

Table 2

The efficiency of Gypsophila uralensis regeneration by callusogenesis WPM medium

\begin{tabular}{|c|c|c|c|}
\hline Growth Regulators, mg / 1 & $\begin{array}{c}\text { The share of shoots with } \\
\text { roots, } \%\end{array}$ & Shoot length, sm & $\begin{array}{c}\text { The number of pairs of } \\
\text { leaves, pcs }\end{array}$ \\
\hline IAA 0.1 & $52.9 \pm 3.9^{\mathrm{a}}$ & $1.7 \pm 0.2^{\mathrm{c}}$ & $3.9 \pm 0.2^{\mathrm{bc}}$ \\
\hline IAA 1.0 & $50.8 \pm 4.8^{\mathrm{a}}$ & $2.3 \pm 0.2^{\mathrm{b}}$ & $4.7 \pm 0.2^{\mathrm{b}}$ \\
\hline IAA 0.2+ IBA 0.5 & $50.8 \pm 6.3^{\mathrm{a}}$ & $2.8 \pm 0.1^{\mathrm{a}}$ & $5.7 \pm 0.2^{\mathrm{a}}$ \\
\hline $\begin{array}{c}\text { The control } \\
\text { (without hormones) }\end{array}$ & $9.6 \pm 2.0^{\mathrm{c}}$ & $1.3 \pm 0.1^{\mathrm{d}}$ & $3.3 \pm 0.1^{\mathrm{c}}$ \\
\hline
\end{tabular}

${ }^{\mathrm{a}-\mathrm{d}}$ Significance indicators of differences in the Duncan test $(\mathrm{P}=0.05)$, where different letters after the average value in the columns show that the differences are significant, the same letters - no differences. 


\section{Conclusion}

Thus, we showed the possibility of obtaining a cell culture (callus from a seedling) and reproduction of G. uralensis by callus genesis. Primary and transfer calluses have a high morphogenic activity and a high multiplication factor for four passages. Callus cells have different competencies on nutrient media of different composition. The roots are formed when auxins are added into the nutrient medium; shoots are formed by the addition of gibberellins, cytokinins and auxins. Changing the nutrient medium from MS to SCS with a complex set of growth regulators helps to obtain a conglomerate of adventitious buds. $90 \%$ of the buds germinate and produce normally developed shoots. The rhizogenesis share is 53 $\%$ on the WPM medium with the addition of IAA auxins from $0.1 \mathrm{mg} / 1$ to $1.0 \mathrm{mg} / 1$. The production of regenerated plants takes $110-150$ days from the start of cultivation.

\section{Acknowledgements}

The work was performed as part of the state assignment on the topics "Regularities of the resource plants's reproduction processes in culture in the European Northeast" (No. AAAAA17-117122090004-9), "Diversity of the plant world of the western macro slope of the Subpolar Urals" (No. AAAAA-A19-119011790022-1).

\section{REFERENCES /ЛИTEРАТУРА}

Ambros E. V., Kotsupu O. V., Novikova T. I., Vysochina G. I. 2018. Clonal micropropagation of Astragalus sericeocanus Gontsch. and content of phenolic compounds in vitro. Turczaninowia 21, 4: 87-99. [In Russian] (Амброс E. В., Коцупий О. В., Новикова Т. И. Высочина Г. И. Клональное микроразмножение редкого вида Astragalus sericeоcanu Gontsch. и содержание фенольных соединений в условиях in vitro // Turczaninowia, 2018. Т. 21, № 4. C. 87-99). DOI: 10.14258/turczaninowia.21.4.10

Andreicheva L. N. 2002. Pleystotsen Yevropeyskogo Severo-Vostoka [Pleistocene European Northeast]. Ekaterinburg: UrO RAN. 323 pp. [In Russian] (Андреичева Л. Н. Плейстоцен Европейского Северо-Востока. Екатеринбург: УрО РАН, 2002. 323 с.).

Butenko R. G. 1964. Kultura izolirovannykh tkaney i fiziologiya morfogeneza rasteniy [Culture of isolated tissues and physiology of plant morphogenesis]. Moscow: Nauka. 272 pp. [In Russian] (Бутенко P. Г. Культура изолированных тканей и физиология морфогенеза растений. М.: Наука, 1964. 272 с.).

Del Vecchio S., Pierce S., Fantinato E., Buffa G. 2019. Increasing the germination percentage of a declining native orchid (Himantoglossum adriaticum) by pollen transfer and outbreeding etween populations. Plant Biology 21(5): 935-941. DOI: 10.1111/plb.12986

Erst A. A., Erst A. S., Shmakov A. I. 2018. In vitro propagation of rare species Rhodiola rosea from Altai Mountains. Turczaninowia 21, 4: 78-86. DOI: 10.14258/turczaninowia.21.4.9

Erst A. A., Yakubov V. V. 2019. Regenerative in vitro capacity of rare species Rhodiola rosea L. from various habitats. Contemporary problems of ecology 12(4): 368-376. DOI: 10.1134/S1995425519040037

Gorchakovskiy P. L. 1963. Endemic and relict elements in the flora of the Urals and their origin. In: Materialy po istorii flory i rastitelnosti SSSR [Materials on the history of flora and vegetation of the USSR]. Iss. IV. Moscow, Leningrad: Izd-vo AN SSSR. Pp. 285-375. [In Russian] (Горчаковский П. Л. Эндемичные и реликтовые элементы во флоре Урала и их происхождение // Материалы по истории флоры и растительности CCCP. Вып. IV. М.-Л.: Изд-во АН СССР, 1963. С. 285-375).

Gorchakovskiy P. L. 2008. Gypsophila uralensis Less. In: Krasnaya kniga Sverdlovskoy oblasti: zhivotnyye, rasteniya, griby [Red Data Book of the Sverdlovsk region: animals, plants, mushrooms]. Ekaterinburg: Basko. P. 155. [In Russian] (Горчаковский П. Л. Gypsophila uralensis Less. // Красная книга Свердловской области: животные, растения, грибы. Екатеринбург: Баско, 2008. С. 155).

Ivashuk O. A., Batlutskaya I. V., Shcherbinina N. V. 2017. Approaches to the construction of simulation model of the process optimization of rare plants microclonal propagation. International journal of advanced biotechnology and research 8(4): 2187-2192.

Ivashchuk O. A., Batlutskaya I. V., Maslova E. V. 2018. Approaches to conservation of biodiversity of rare and endangered medicinal plants on the basis of microclonal multiplication with optimization of parameters by methods of neural network modeling. Research journal of pharmaceutical biological and chemical 9(5): 2347-2356.

Kalashnikova E. A., Rodin A. R. 2004. Polucheniye posadochnogo materiala drevesnykh, tsvetochnykh $i$ travyanistykh rasteniy s ispolzovaniyem metodov biotekkhnologii: Uchebnoye posobiye 3 izd., ispr. i dop. [Obtaining planting material for woody, floral and herbaceous plants using biotechnology methods]. Moscow: MGUL. 84 pp. [In Russian] (Калашникова E. A., Родин $\boldsymbol{A}$. P. Получение посадочного материала древесных, цветочных и 
травянистых растений с использованием методов биотехнологии: Учебное пособие 3-е изд., испр. и доп. М.: МГУЛ, 2004. 84 с.).

Kalinin V. F. Kushnir G. P., Sarnackaya V. V. 1992. Tekhnologiya mikroklonalnogo razmnozheniya rasteniy [Technology of microclonal propagation of plants]. Kiev: Naukova Dumka. 227 pp. [In Russian] (Калинин В. Ф. Кушнир Г. П., Сарнацкая В. В. Технология микроклонального размножения растений. Киев: Наукова Думка, 1992. 227 c.).

Kamelin R. V. 2008. Gypsophila uralensis Less. subsp. pinegensis (Perf.) R. Kam. (G. pinegensis Perf.). In: Krasnaya kniga Rossiyskoy Federatsii (rasteniya i griby) [Red Data Book of the Russian Federation (plants and fungi)]. Moscow: Tovarishchestvo nauchnykh izdaniy KMK. P. 167. [In Russian] (Камелин P. В. Gypsophila uralensis Less. subsp. pinegensis (Perf.) R. Kam. (G. pinegensis Perf.) // Красная книга Российской Федерации (растения и грибы). М.: Тов-во науч. изд. КМК, 2008. С. 167).

Kataeva N. V., Butenko R. G. 1983. Klonalnoye mikrorazmnozheniye rasteniy [Clonal micro-propagation of plants]. Moscow: Nauka. 96 pp. [In Russian] (Катаева Н. В., Бутенко Р. Г. Клональное микроразмножение растений. М.: Наука, 1983. 96 с.).

Kritskaya T. A., Blyudneva E. A., Kashin A. S. 2015. Pitatelnaya sreda dlya mikrorazmnozheniya kalcefilnykh rasteniy $v$ kulture in vitro [Nutrient medium for micro-propagation of calcefilic plants in culture in vitro]. Patent na izobreteniye [Invention patent] RU №2552174 S1, MPK S 12N5/00 (2006.1). 10.06.2015. Byull. № 16. [In Russian] (Крицкая T. A., Блюднева $\boldsymbol{E}$. $\boldsymbol{A}$., Кашин $\boldsymbol{A}$. $\boldsymbol{C}$. Питательная среда для микроразмножения кальцефильных растений в культуре in vitro. Патент на изобретение RU №2552174 C1, МПК С 12N5/00 (2006.1). Опубл. 10.06.2015. Бюл. № 16).

Kritskaya T. A., Kashin A. S., Spivak V. A. Firstov V. E. 2016. Eatures of clonal micropropagation of Silene cretacea (Caryophyllaceae) in in vitro culture. Journal of Developmental Biology 47(6): 386-394. [In Russian] (Kрицкая Т. А., Кашин А. С., Спивак В. А., Фирстов В. Е. Особенности клонального размножения Silene cretacea (Caryophyllaceae) в культуре in vitro // Онтогенез, 2016. T. 47, № 6. С. 386-394). DOI: 10.7868/S0475145016060021

Lloyd G., McCown B. 1980. Commercially-feasible micropropagation of mountain laurel, Kalmia latifolia, by use of shoot-tip culture. Proc. Int. Plant Prop. Soc. 30: 421-427.

Murashige T., Skoog F. 1962. A revised medium for rapid growth and bioassays with tobacco tissue cultures. Physiol. Plant 15(13): 473-497.

Perfilyev I. A. 1941. Gypsophila pinegensis Perf. sp. n. Bot. Zhurn. (Moscow \& Leningrad) 26(1): 28-33. [In Russian] (Перфильев И. А. Gypsophila pinegensis Perf. sp. n. // Бот. журн., 1941. Т. 26, № 1. С. 28-33).

Puchnina L. V. 2008. Gypsophila uralensis Less. subsp. pinegensis (Perf.) Kamelin. In: Krasnaya kniga Arkhangelskoy oblasti [Red Data Book of the Arkhangelsk region]. Arkhangelsk: Administratsiya Arkhangelskoy oblasti. Pp. 170-171. [In Russian] (Пучнина Л. В. Gypsophila uralensis Less. subsp. pinegensis (Perf.) Kamelin // Красная книга Архангельской области. Архангельск: Администрация Архангельской обл., 2008. С. 170-171).

Sathe M., Vibhute M., Jain M., Srivastav P. 2013. A novel method for efficient micropropagation of Radermachera xylocarpa (roxb.) k. schum., a rare medicinally important forest srecies. Plant tissue culture and biotechnology . 23(1): 21-29. DOI: 10.3329/ptcb.v23i1.155569

Teteryuk L. V. 2009. Gypsophila uralensis Less. s. 1. In: Krasnaya kniga Respubliki Komi [Red Data Book of the Komi Republic]. Syktyvkar: Komi respublikanskaya tipografiya. Pp. 454-455. [In Russian] (Тетерюк Л. В. Gypsophila uralensis Less. s. 1. // Красная Книга Республики Коми. Сыктывкар: Коми республиканская типография, 2009. C. 454-455).

Teteryuk L. V., Chadin I. F., Shadrin D. M., Pylina Ya. I., Puchnina L. V. 2018. Genetic Differentiation of the Ural Endemic Gypsophila uralensis (Caryophyllaceae) in Relict Fragments of Its Range in Northwestern European Russia. Russian Journal of Ecology 49(2): 102-110. DOI: 10.1134/S1067413618020133 